\title{
A Simple Method to Map Groundwater Depth and Water Quality for Leogane, Haiti and Elsewhere
}

\author{
Michael E. Kalinski \\ Professor, University of Kentucky \\ Lexington, KY 40506-0281 \\ michael.kalinski@uky.edu \\ Nicholas Duda \\ Geotechnical EIT, Stantec \\ Lexington, KY 40513 \\ Nick.Duda@stantec.com \\ Herby Lissade \\ President, Haiti Engineering \\ Elk Grove, CA 95624 \\ herbylissade@icloud.com \\ Harry Donaghy \\ Staff Geotechnical Engineer, AECOM \\ Greenwood Village, CO 80111 \\ harrydonaghy@.comcast.net
}

Abstract - In the aftermath of the January 2010 Haiti Earthquake, the streets of downtown Leogane were paved to mitigate waterborne disease using humanitarian relief funds. After paving, many of the shallow water wells in Leogane dried up. It was believed that the new pavement disrupted groundwater recharge and negatively impacted the wells. Therefore, a project was performed to assess groundwater conditions in a cost-effective manner using a rapid, inexpensive, non-intrusive geophysical approach. The scope of the project included 1) surveying the new pavement system, 2) surveying water wells in Leogane, 3) testing the well water for coliforms, 4) performing geophysical DC resistivity testing to map groundwater depth and 5) developing a groundwater map to assess the impact of the pavement on the water table. As a result of this project, it could not be concluded that the new pavement was a factor in the groundwater fluctuations observed in the water wells in Leogane. It is more likely that some of the drop in the water table was due to the earthquake itself, and some of it was caused by seasonal fluctuations in the water table. It was also observed that all the wells that extract water from shallow (less than $6 \mathrm{~m} \mathrm{deep}$ ) aquifers in Leogane contain coliforms due to their proximity to household latrines, although a second deeper aquifer was identified and found to be coliform-free. With respect to broader impact, this methodology represents a relatively simple approach to mapping groundwater and assessing water quality that can be easily applied to other communities in the developing world to guide their efforts to develop and manage groundwater.

Index Terms - Haiti, groundwater, geophysics, water testing, coliforms 


\section{INTRODUCTION}

Haiti (pop. 11.4 million) is one of the most impoverished nations in the world. According to statistics compiled by the World Bank ${ }^{1}$, the per capita Gross Domestic Product (GDP) of Haiti in 2018 was approximately $\$ 870$, and over 6 million Haitians were living on a daily income of less than USD $\$ 2.41$. Haiti is also highly susceptible to strong ground motion as evidenced by the January 12, 2010 Haiti Earthquake, which led to catastrophic loss of life with an estimated 250,000 fatalities and $\$ 8$ billion in damage ${ }^{2}$.

In the aftermath of the 2010 Haiti Earthquake, humanitarian relief funds poured into Haiti. Prior to the earthquake, the downtown area of Leogane, which is only a few miles from the epicenter, was highly susceptible to flooding during large rain events, which created problems with transportation and exacerbated a post-earthquake cholera outbreak. There were no paved roads or any sort of storm water drainage system in Leogane prior to the 2010 earthquake. To mitigate this effect, the Japanese government ${ }^{3}$ contributed 1.45 billion yen (USD $\$ 12.6$ million) to improve approximately $11 \mathrm{~km}$ of paved streets and $2 \mathrm{~km}$ of storm water conveyance systems in 2010-2012 (Fig. 1). Roads were improved in the central part of Leogane where population density is the highest. Existing roads were graded smooth and re-surfaced with a layer of crushed rock, sand and concrete pavers, which were vibrated into place to improve subgrade density and road stability. Concrete-lined drainage culverts were installed on both sides of the newly re-paved roads with inlets at the street corners to manage storm water. Storm water from the system was diverted to a nearby stream that was able to accommodate the flow without flooding. Flooding in Leogane was significantly mitigated as a result of the new pavement. (Fig. 2).

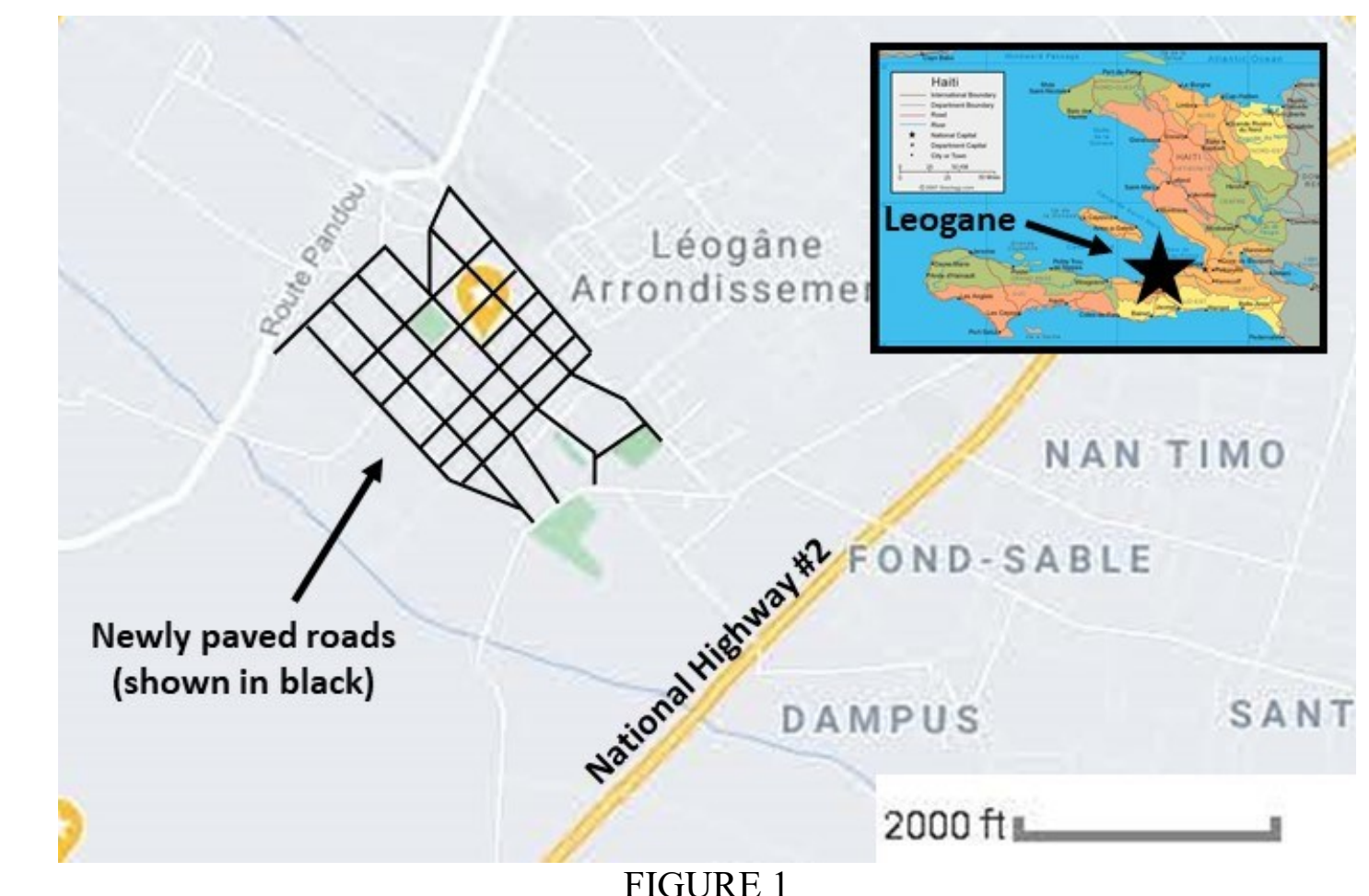

MAP OF LEOGANE SHOWING THE APPROXIMATE LOCATION OF THE NEWLY PAVED ROADS. 


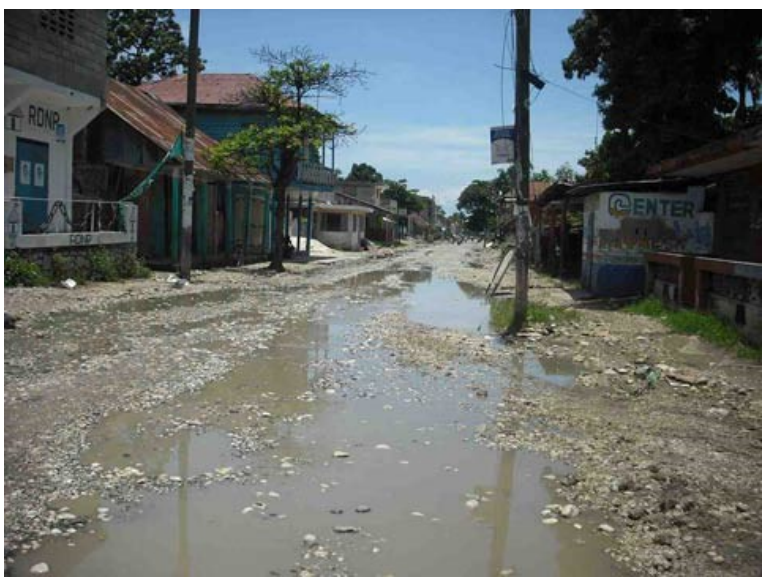

a. Before road improvement

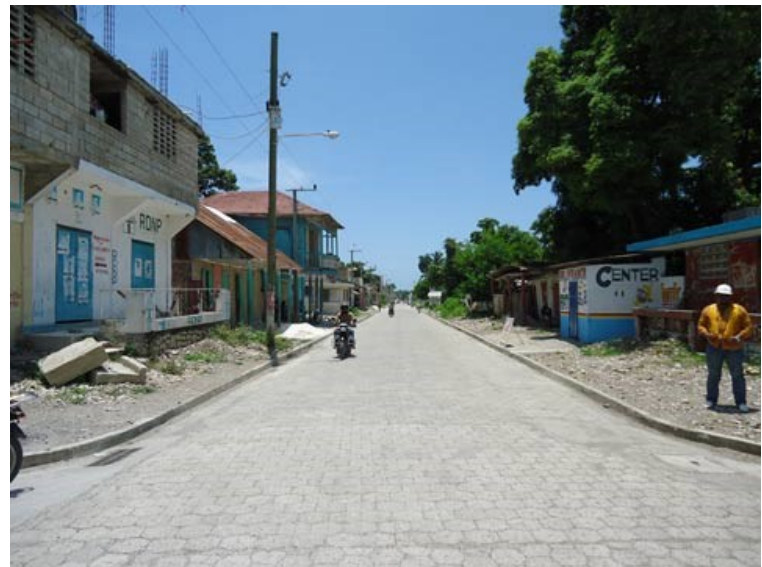

b. After road improvement

FIGURE 2

ROUTE R38 IN LEOGANE BEFORE AND AFTER CONSTRUCTION OF A NEW PAVEMENT AND DRAINAGE SYSTEM ILLUSTRATING THE IMPROVEMENT IN ROAD CONDITIONS.

Leogane (pop. 165,000) is situated on a coastal plain that dips gently at a rate of less than $1 \%$ from the mountains in the southeast to the Caribbean Sea in the northwest, with an elevation at the center of town of approximately $20 \mathrm{~m}$ above sea level. Many of the residents in Leogane rely on shallow hand-excavated water wells (Fig. 3). These wells can be found at private residences and public locations such as churches. There are hundreds of wells in Leogane, with some dating as far back as the 1700s. Near-surface soils in Leogane consist of silty, sandy soils with moderate to high permeability. As a result, the water table in Leogane has historically been quick to recharge, and the water wells had been productive and reliable sources of water until the beginning of 2013 .

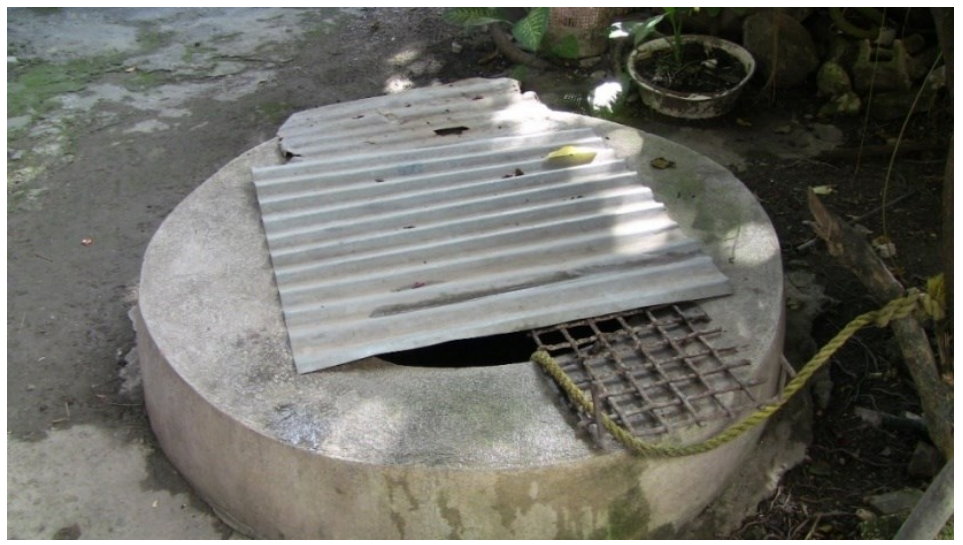

FIGURE 3

TYPICAL WATER WELL IN LEOGANE (IDENTIFIED AS WELL \#1 IN TABLE 1) YIELDING WATER FROM A DEPTH OF 2.0 M BELOW THE GROUND SURFACE IN SUMMER 2013. THIS WELL CEASED TO BE PRODUCTIVE IN 2014.

The time when the wells in Leogane began to dry up did not correlate to a significant reduction in precipitation (Fig. 4). For example, the water depth in Well \#1 (as identified in Table 1) varied significantly over the period of 2013 to 2018. This period included a normal 
period of precipitation followed by a dry spell. However, the water in the well was observed to be shallowest during a dry period and deepest during a period of normal precipitation. Therefore, precipitation patterns were ruled out as a possible cause of the increase in water depth. Instead, it was believed that the increase in water depth was caused by the new pavement and storm water drainage system, which disrupted the natural groundwater recharge.

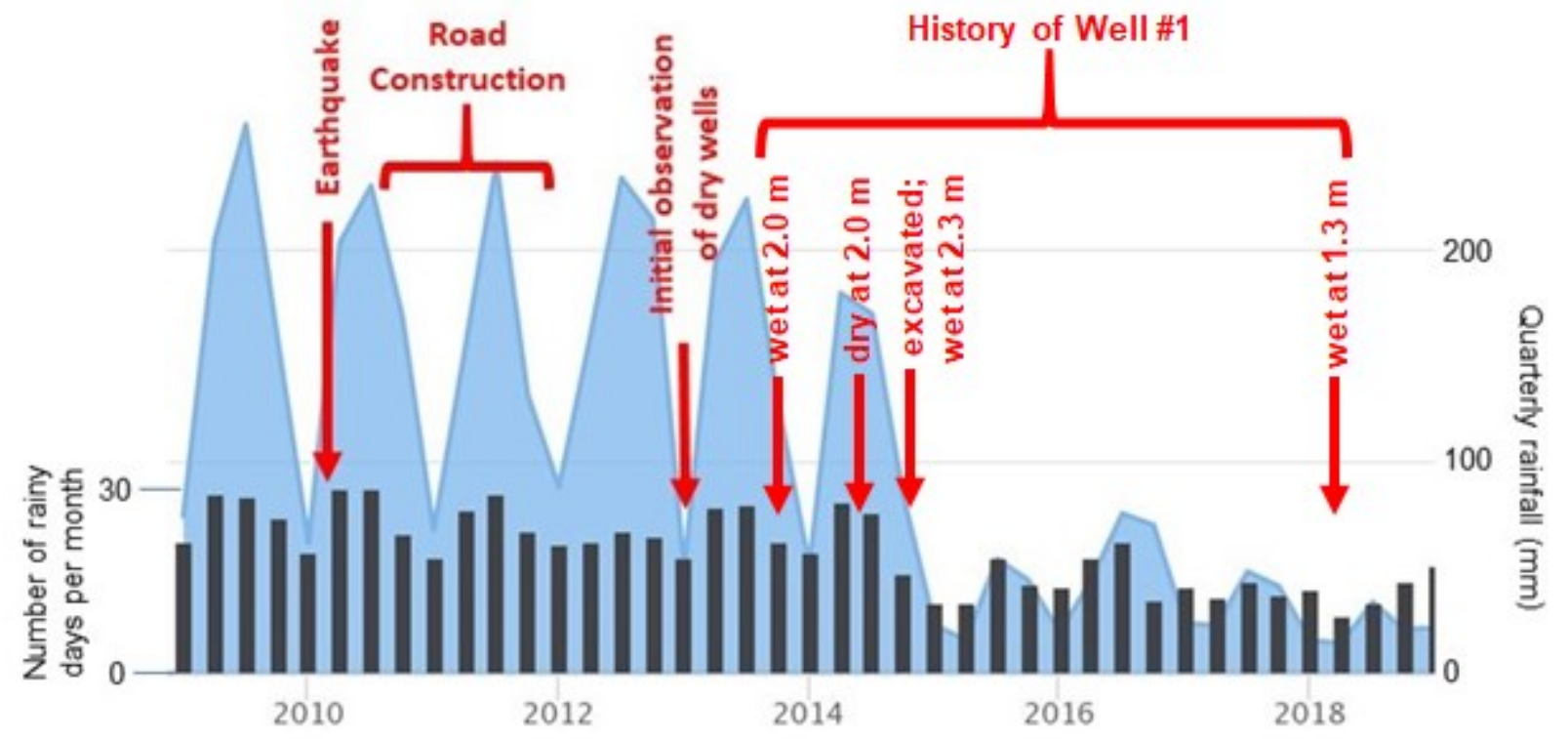

FIGURE 4

QUARTERLY RAINFALL AMOUNT IN LEOGANE (BLUE GRAPH) AND NUMBER OF RAINY DAYS PER MONTH (BLACK BAR CHART) DURING THE 2009-2018 TIME FRAME4.

Remediation of these wells typically consists of excavating the well to a greater depth. In one instance, a water well (Well \#1) that was historically productive at a depth of $2.0 \mathrm{~m}$ below the ground surface was successfully remediated by excavating the well by hand to a depth of 2.3 $\mathrm{m}$ (Fig. 5). However, this strategy may not always be successful, especially if the groundwater has been drawn down to a depth beyond which the well can be safely excavated. Ideally, it would be beneficial to map the depth to groundwater to develop a more efficient and effective strategy for well remediation.

The humanitarian project described herein was funded by Geoscientists Without Borders and completed by faculty and students at the University of Kentucky. It was intended to address the issue of water wells in Leogane that had been presumably rendered nonproductive due to construction of the new pavement and storm water management systems. The project included mapping of the newly paved roads and storm water management system and mapping and water testing of existing water wells in Leogane to ascertain their performance and establish groundwater conditions. Electrical DC resistivity testing was also used as a nondestructive, nonintrusive geophysical technique to supplement the water well survey and aid in developing a comprehensive understanding of the near-surface hydrogeology in Leogane. 


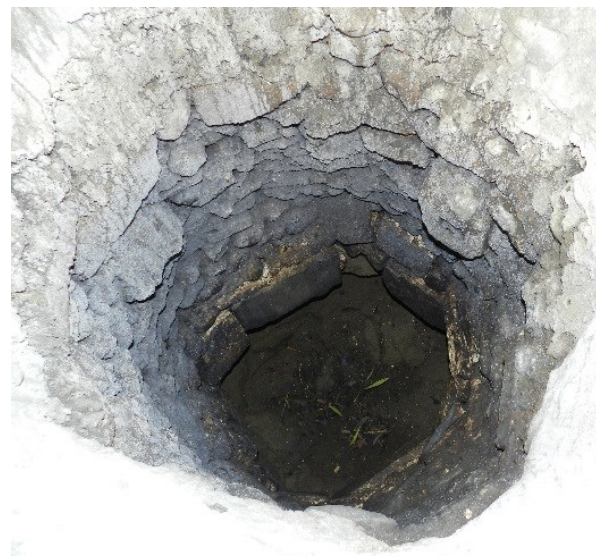

a. Before excavation (dry at $2.0 \mathrm{~m}$ )

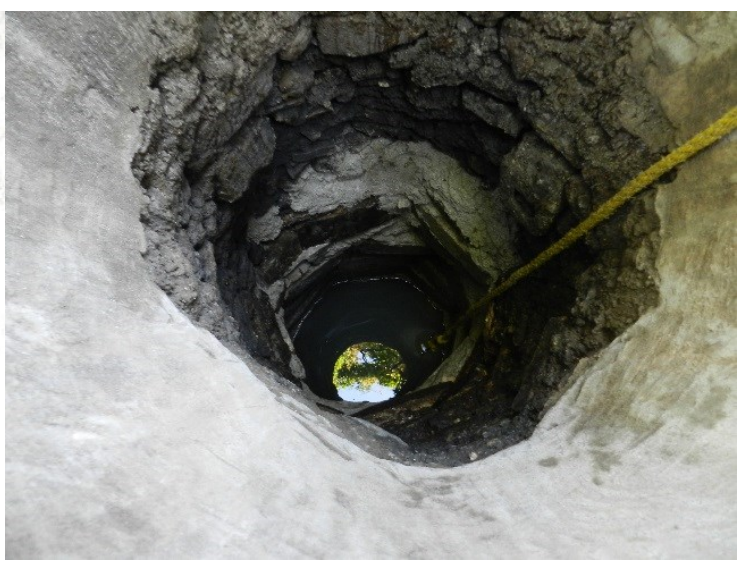

b. After excavation (productive at $2.3 \mathrm{~m}$ )

\section{FIGURE 5}

WELL \#1 IN LEOGANE THAT CEASED TO BE PRODUCTIVE IN 2014 AFTER ROAD CONSTRUCTION (LEFT) BUT WAS SUCCESSFULLY REMEDIATED BY EXCAVATION (RIGHT).

\section{Methods and Field Testing Program}

The Leogane investigation employed electrical direct-current (DC) resistivity sounding as a nonintrusive geophysical exploration tool to aid in groundwater mapping. Electrical direct-current (DC) resistivity sounding is an established method for estimating variations in electrical resistivity with depth in a layered soil or rock system ${ }^{5}$. The method has traditionally employed the use of four electrodes installed into the ground surface in a straight line (Fig. 6). The electrodes are steel spikes that are pushed into the ground about $10-15 \mathrm{~cm}$. The ground surface typically has enough moisture to allow current to pass from the soil into the electrode, but in instances where the ground surface is exceptionally dry, water can be poured onto the installed electrodes to improve electrical coupling.

Current $(I)$ is passed through two outer electrodes while voltage $(V)$ is measured across two inner electrodes as electricity flows through the ground. Voltage measurements taken with small electrode spacings are affected by the electrical resistivity of the shallower strata, while measurements taken with larger spacings are affected by the properties of the shallower and deeper strata. By varying the position of the electrodes, the measured voltage changes, and apparent resistivity (a function of measured voltage divided by applied current), $\rho_{a}$, is plotted versus electrode spacing. Apparent resistivity is expressed as:

$\rho_{a}=2 \pi a V / I$

where:

$I$ = current applied across electrodes A and B;

$V=$ voltage measured across electrodes $\mathrm{M}$ and $\mathrm{N}$; and

$a=$ electrode spacing.

The Wenner array field electrode configuration (the type used in the Leogane study described herein) is the simplest configuration and consists of four electrodes placed in a straight line with a uniform spacing equal to $a$ as depicted in Fig. 6. To perform a test, measurements are made 
using a range of short, intermediate and long electrode spacings and $\rho_{a}$ is plotted as a function of $a$ as depicted in Fig. 7. As electrode spacing is increased, the depth of the electrical flow also increases as the electricity passes through deeper and deeper strata. Therefore, measurements taken with small electrode spacings are affected by the electrical properties of the shallower layers, while measurements taken with larger electrode spacings are affected by the electrical properties of the deep and the shallow layers. Thus, variations in electrical resistivity with electrode spacing can be used to calculate variations in electrical resistivity with depth, which can be interpreted to estimate the depth to the water table.

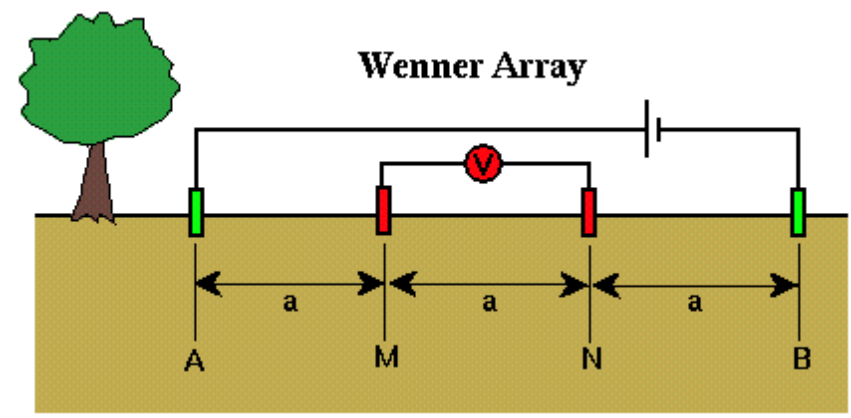

FIGURE 6

TYPICAL WENNER ARRAY CONFIGURATION FOR ACQUIRING DC RESISTIVITY FIELD DATA.

Apparent resistivity is a qualitative indicator of variations in resistivity with depth. In the schematic example shown in Fig. 7a, apparent resistivity decreases with increasing electrode spacing. This indicates qualitatively that the true resistivity of the ground is decreasing with increasing depth. Variations in true resistivity with depth are then quantified through the process of numerical inversion to develop a sounding of true electrical resistivity versus depth (Fig. 7b). The one-dimensional sounding may be interpreted to infer subsurface conditions. Since the true resistivity of soil and rock is mostly controlled by the presence and salinity of pore water, DC resistivity soundings are a valuable tool for ascertaining subsurface groundwater conditions, including groundwater quality and depth to the water table.

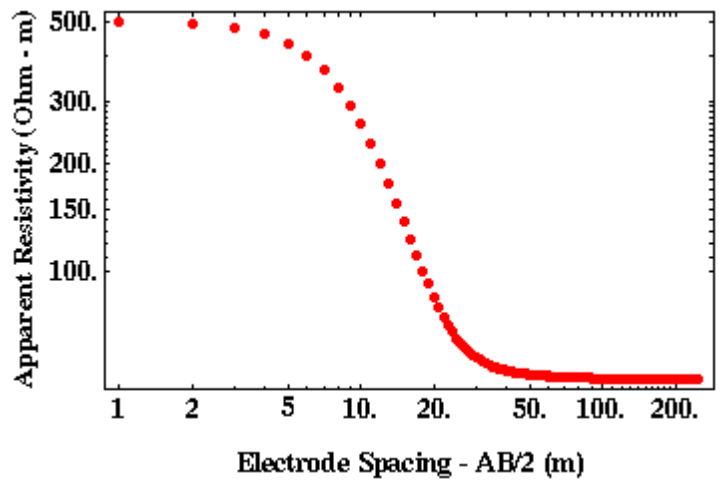

a. Apparent resistivity curve

FIGURE 7

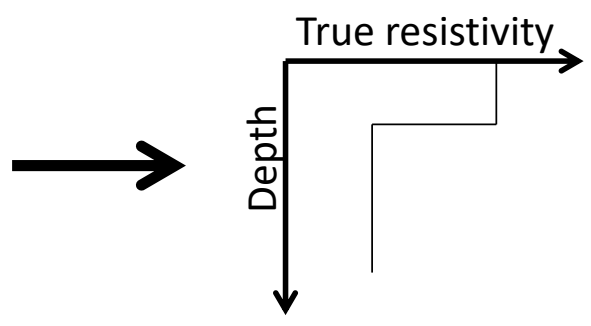

b. True resistivity sounding

CURVE SHOWING APPARENT RESISTIVITY VERSUS ELECTRODE SPACING ACQUIRED DURING FIELD DC RESISTIVITY TESTING AND SOUNDING OF TRUE RESISTIVITY VERSUS DEPTH DERIVED FROM INVERSION OF THE APPARENT RESISTIVITY CURVE. 
In the past 20 years, traditional four-electrode systems have given way to sophisticated systems consisting of dozens of electrodes where measurements are automated, and data are inverted to create two-dimensional resistivity profiles ${ }^{6}$. In the field, these state-of-the-art systems are relatively equipment-intensive and typically consist of large batteries, a control box, a switch box, cables, and dozens of electrodes. They are also relatively expensive with costs in the tens of thousands of dollars. In locations such as Haiti where equipment support is minimal, it is advantageous to use simpler field equipment to facilitate testing and minimize delays.

For this project, an L \& R Instruments MiniRes DC resistivity system was acquired and used for field testing (Fig. 8). Field testing with the MiniRes meter is a relatively easy process that can be learned in a few minutes. For this study, testing was performed by a group of one faculty and two students. This system is a simple four-electrode system consisting of a small rugged box powered by four D-cell batteries. It is highly portable and is ideally suited for field testing in places such as Leogane. This system costs approximately $\$ 6,000$. Inversion of the field data was performed using the Interpex IXID software, which costs approximately $\$ 1,000$. With this approach, one-dimensional soundings showing variations in true resistivity with depth were derived and interpreted to infer groundwater conditions in the field.

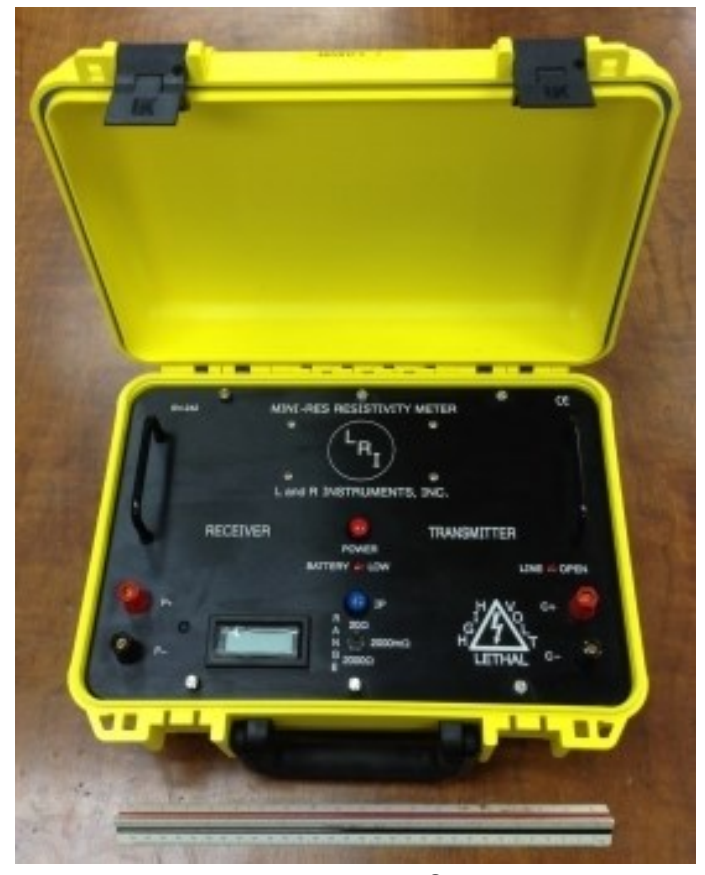

FIGURE 8

L \& R INSTRUMENTS MINIRES FOUR-ELECTRODE DC RESISTIVITY SYSTEM.

The field study was performed in and around Leogane where the new pavement and storm water management system were believed to have negatively impacted the performance of water wells used by the community (Fig. 9). Field activities were performed in the January 30 to February 8, 2018 time frame. The main activities in the investigation are described in the following paragraphs.

Mapping of new pavement and storm water management system. The objective of this task was to obtain an accurate survey of the location of all new pavement and storm water 
management features that may have negatively impacted the water wells in Leogane. The new pavement and storm water management system consists of approximately $11 \mathrm{~km}$ of pavement and $2 \mathrm{~km}$ of storm water management structures throughout the central area of Leogane. Results of this task revealed that the location of the new pavement system in Leogane was consistent with the estimated location of the pavement system depicted in Fig. 1.

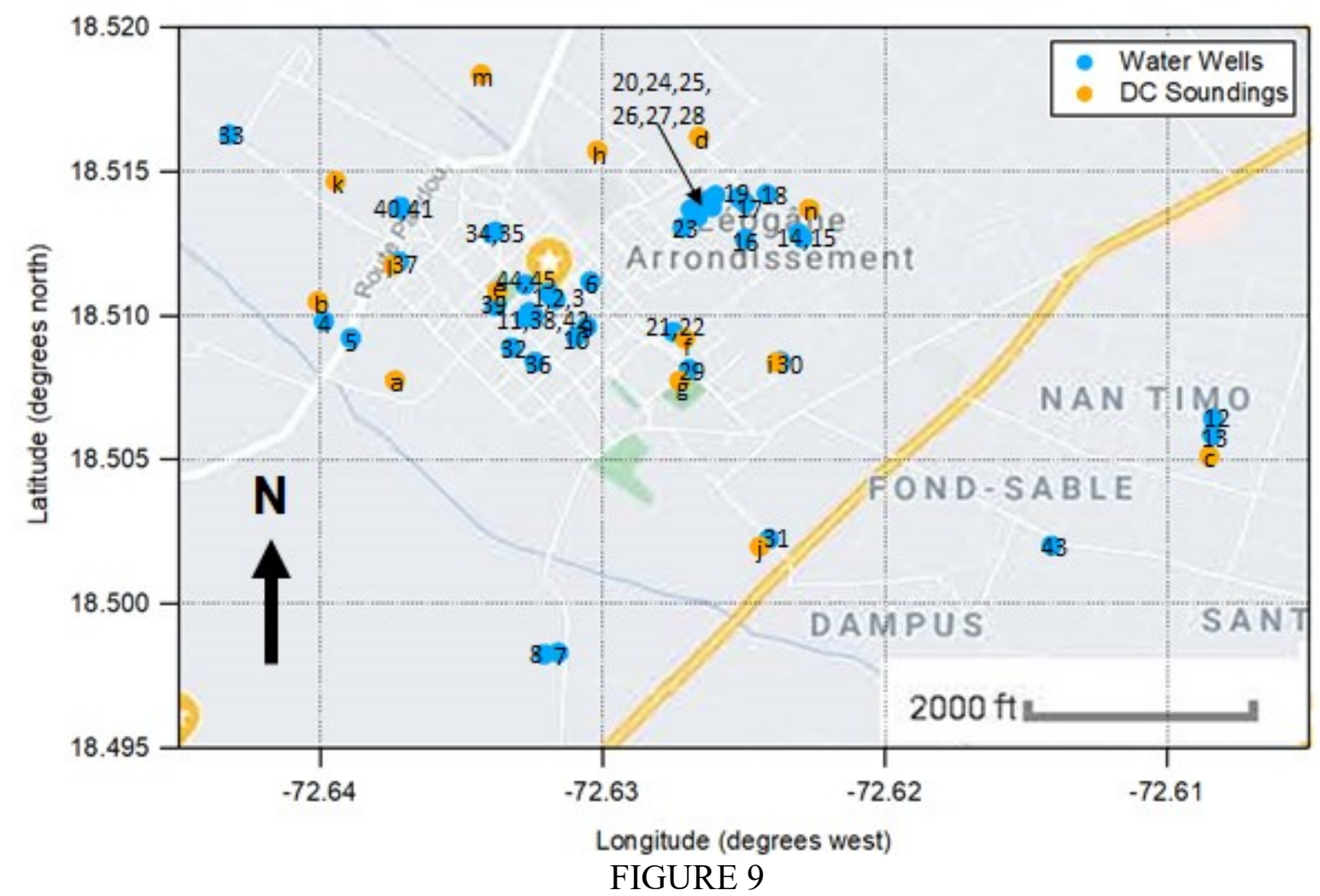

MAP OF FIELD STUDY AREA IN LEOGANE SHOWING THE NUMBERED LOCATION OF SURVEYED WATER WELLS AND LETTERED LOCATION OF DC RESISTIVITY SOUNDINGS; REFER TO TABLE 1.

Mapping and water testing of wells in Leogane. The objective of this task was to gather information about water wells in and around Leogane to contribute to the overall understanding of local hydrogeological conditions. A total of 45 wells were surveyed. Surveying included measuring of water table depth below the ground surface with a steel tape, water sampling and field testing for $\mathrm{pH}$, electrical conductivity, temperature, and total dissolved solids (Fig. 10). Field testing was performed using a small Hanna hand-held meter.

The well water was also tested for the presence of coliforms using a robust field method described by Manja et $\mathrm{al}^{7}$. Using this method, the water is mixed at room temperature with a Pathoscreen packet, which contains sulfur-rich nutrients (Fig. 11). Microorganisms that occur with coliforms anaerobically metabolize the nutrients and turn the water black, so inspection of the water a few days after sampling clearly reveals the presence or absence of coliforms. This method is very well suited for testing in developing nations because it is fast, inexpensive (about $\$ 1$ per test), and does not require special equipment or an oven to incubate the water samples. 
The Pathoscreen method developed by Manja et al. was originally calibrated by testing it against an established lab-based Most Probable Number (MPN) method. Water samples with a coliform count of 10 per $100 \mathrm{~mL}$ as assessed by the MPN method and water samples that turned the sample black using the Pathoscreen method were graded as unsatisfactory. Using these criteria, the two methods were found to be $88.34 \%$ in agreement over a population of 669 samples. Thus, it can be concluded that the Pathoscreen method has a coliform detection limit of approximately 10 per $100 \mathrm{ml}$.
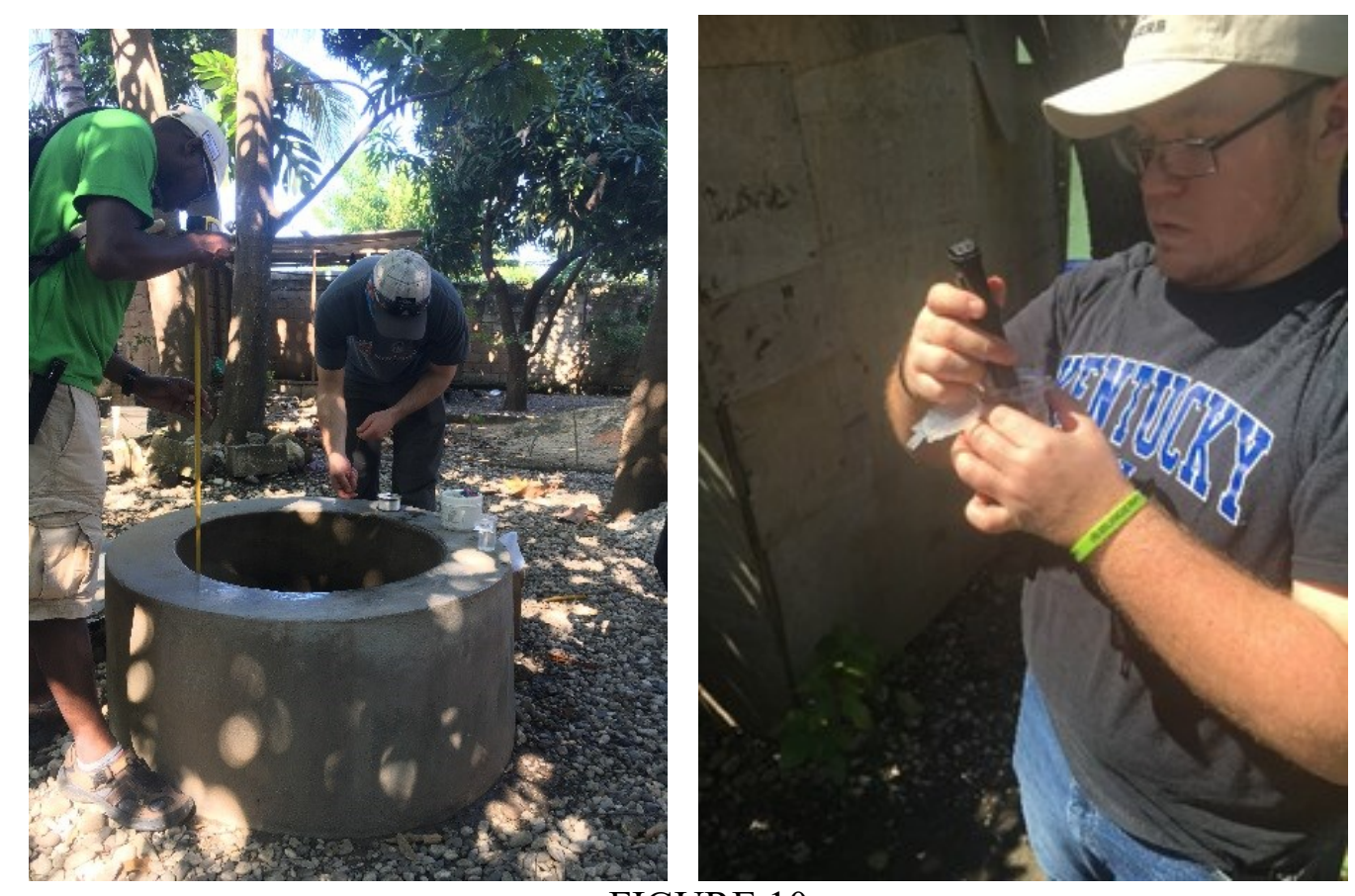

FIGURE 10

PERFORMING WATER SAMPLING AND TESTING USING A SMALL HAND-HELD METER.

Perform DC resistivity testing to supplement the groundwater data. Electrical DC resistivity soundings were performed at 14 locations (orange points in Fig. 9) in Leogane to supplement the water well survey data (blue points in Fig. 9). Each sounding was generated using a Wenner array configuration with 11 electrode spacings ranging from 0.7-27.4 $\mathrm{m}$. The steel electrodes were driven approximately $10-15 \mathrm{~cm}$ into the ground. Since the ground in Leogane was relatively moist, this depth was adequate to achieve good electrical contact between the soil and the electrodes. In situations where the ground is dry, it is helpful to pour water on the electrodes to improve electrical contact, but this practice was not necessary in Leogane. Each test location took around 30-45 minutes to complete. Testing activities at each location included arrival at the location, marking points to place electrodes, installing electrodes and cables, testing for each of the 11 electrode spacings, documenting the results, recording the location by GPS, picking up the equipment and departure from the site.

The L \& R Instruments MiniRes meter was used as shown in Fig. 12. The meter was easy to use and produced reliable results with a relatively simple, portable field configuration. A simpler four-electrode system was selected over a more sophisticated multiple-electrode automated profiling system to minimize cost, expedite testing and provide mobility in the field. Apparent 
International Journal for Service Learning in Engineering, Humanitarian Engineering and Social Entrepreneurship Vol. 16, No. 1, pp. 1-19, Spring 2021

ISSN 1555-9033

resistivity curves were inverted using the Interpex IX1D software to derive soundings of true resistivity versus depth, and depth to the water table was interpreted based on observed reductions in electrical resistivity with depth. Low values for electrical resistivity on the soundings that were indicative of saturated soil were compared to electrical conductivity measurements of the well water to validate the interpretation of the resistivity soundings. After the field data were acquired, the observed water depths in the wells were combined with interpreted water depths from the resistivity soundings to create an overall map showing the depth to the water table throughout Leogane.
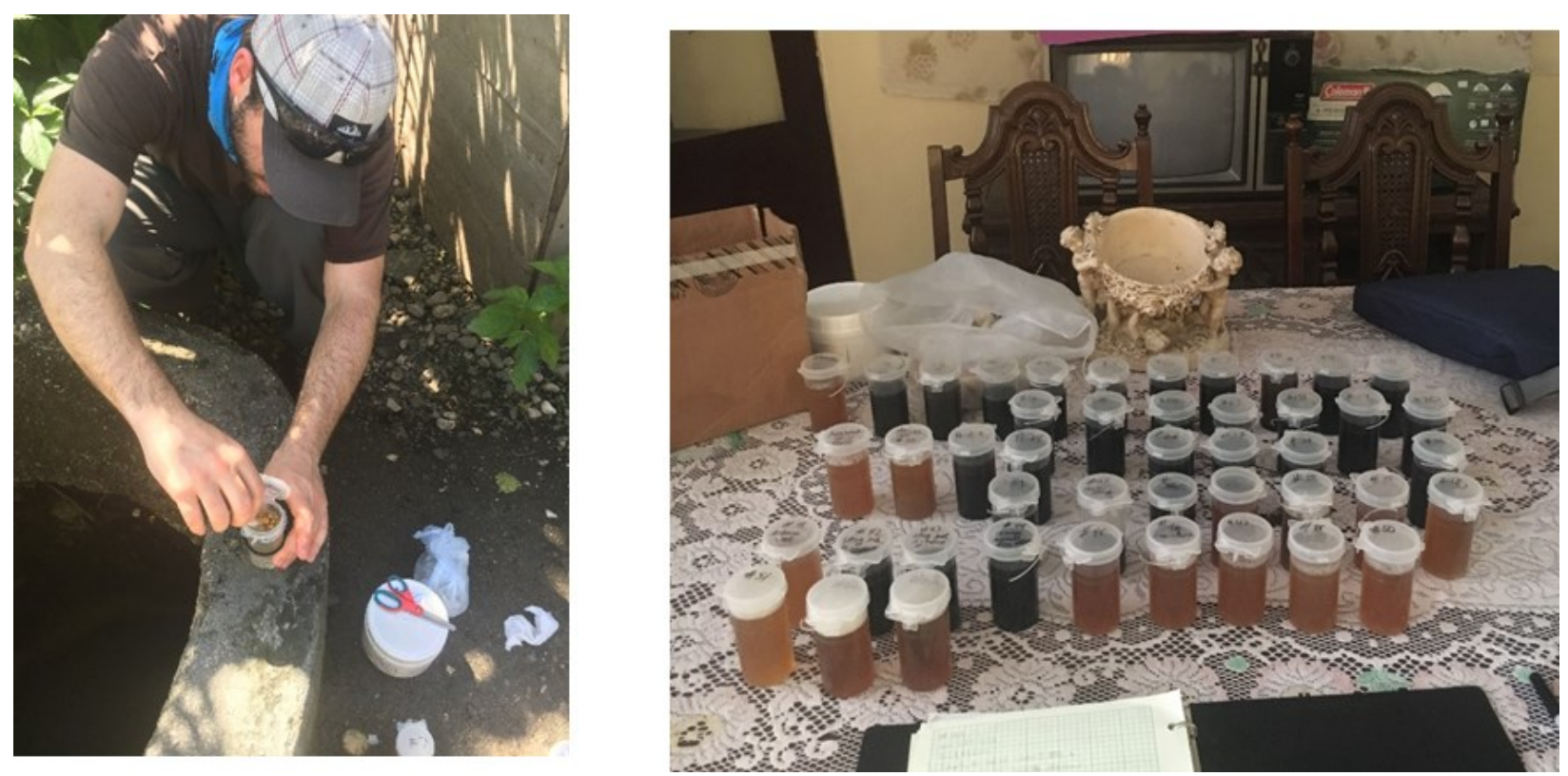

FIGURE 11

PERFORMING PATHOSCREEN TESTING FOR COLIFORMS; RESULTS FROM PATHOSCREEN TESTING OF THE WATER WELLS IN LEOGANE.

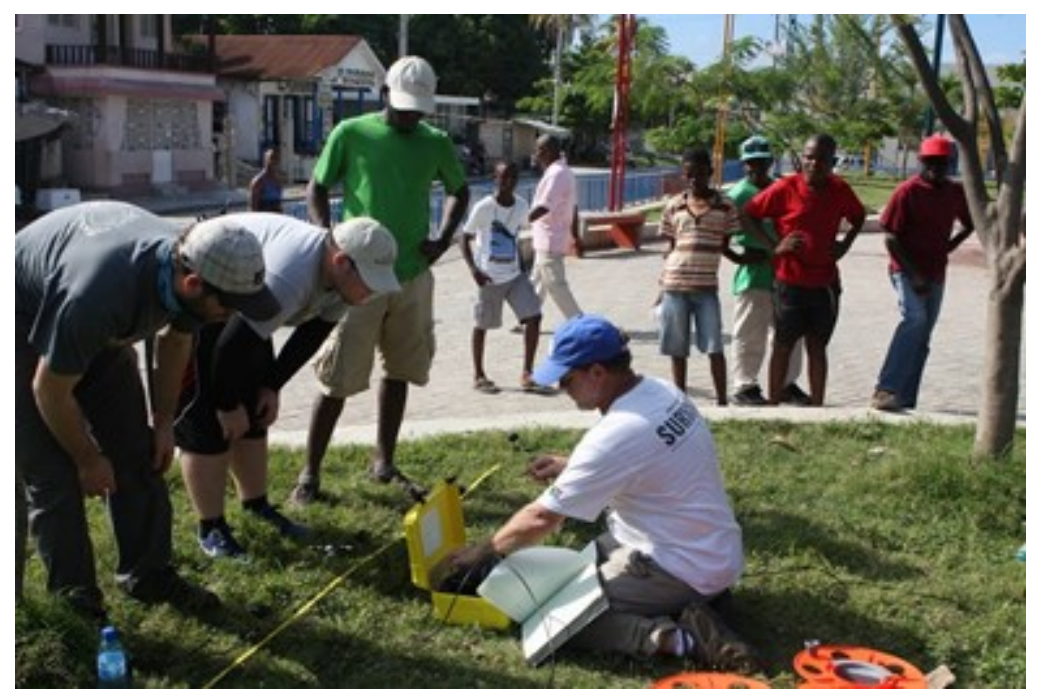

FIGURE 12

PERFORMING ELECTRICAL DC RESISTIVITY TESTING IN LEOGANE AT TEST LOCATION “e”. 


\section{RESULTS}

Field activities were completed by personnel from the University of Kentucky and Haiti Engineering during their visit to Leogane from January 29 - February 9, 2018. Haiti Engineering is a non-government organization (NGO) that provides engineering and technical services in Haiti. For this project, Haiti Engineering provided support and field logistic services while in Haiti. The University of Kentucky and Haiti Engineering were assisted by numerous local friends and acquaintances who provided logistic and field support. A total of 45 water wells were visited as summarized in Table 1. Wells were selected to obtain a relatively uniform distribution of data points for mapping. The data collected for each well included:

- latitude and longitude;

- depth to groundwater;

- $\mathrm{pH}$;

- temperature;

- well water electrical resistivity;

- total dissolved solids (TDS); and

- coliform presence or absence.

Of the 45 water wells, water samples were recovered from 36 of them. The remaining nine wells were either found to be dry or not sampled. All 36 samples yielded $\mathrm{pH}$ measurements that were within the acceptable range of 6.5-8.5 established by the United States Environmental Protection Agency (USEPA) as National Secondary Drinking Water Regulations (NSDWRs). In the United States, the NSDWR criteria are non-enforceable guidelines that are recommended to improve the aesthetic quality of water ${ }^{8}$. Approximately $74 \%$ (29 out of 36) of the samples yielded TDS measurements that were below the NSDWR recommended limit of 0.5 parts per thousand (PPT).

Coliform presence was mapped and is depicted in Figure 13. The coliform data revealed all the water recovered from shallow (less than $9 \mathrm{~m}$ deep) wells contained coliforms. This contamination is attributed to hydraulic communication between the water wells and nearby private latrines, which are common in Leogane and were often less than $10 \mathrm{~m}$ away from the wells. On the other hand, none of the artesian wells tested in Leogane contained coliforms. Residents described the deeper aquifer associated with the artesian wells as an "underground river" known for producing high-quality, clean water. 
International Journal for Service Learning in Engineering,

Humanitarian Engineering and Social Entrepreneurship Vol. 16, No. 1, pp. 1-19, Spring 2021

ISSN 1555-9033

TABLE 1

DATA OBTAINED FROM WATER WELLS IN LEOGANE.

\begin{tabular}{|c|c|c|c|c|c|c|c|c|}
\hline Well \# & $\begin{array}{l}\text { Latitude } \\
(\text { deg. } \mathrm{N})\end{array}$ & $\begin{array}{l}\text { Longitude } \\
\text { (deg. W) }\end{array}$ & $\begin{array}{l}\text { Water } \\
\text { Depth } \\
(\mathrm{m})\end{array}$ & $\mathrm{pH}$ & $\begin{array}{l}\text { Temp. } \\
\left({ }^{\circ} \mathrm{C}\right)\end{array}$ & $\begin{array}{c}\text { Water } \\
\text { Resistivity } \\
\text { (Ohm-m) }\end{array}$ & $\begin{array}{l}\text { TDS } \\
\text { (PPT) }\end{array}$ & $\begin{array}{l}\text { Coliform } \\
\text { Presence }\end{array}$ \\
\hline 1 & 18.510650 & -72.631783 & 1.28 & 6.95 & 28.8 & 15.15 & 0.32 & positive \\
\hline 2 & 18.510550 & -72.631667 & 1.37 & 6.93 & 29.0 & 15.15 & 0.33 & positive \\
\hline 3 & 18.510783 & -72.631900 & 1.16 & 6.96 & 28.2 & 16.39 & 0.31 & positive \\
\hline 4 & 18.509800 & -72.639867 & 0.40 & 7.17 & 27.3 & 5.95 & 0.85 & positive \\
\hline 5 & 18.509217 & -72.638917 & 0.21 & 7.44 & 27.1 & 8.20 & 0.61 & positive \\
\hline 6 & 18.511183 & -72.630433 & 1.52 & 7.24 & 28.5 & 12.20 & 0.41 & positive \\
\hline 7 & 18.498300 & -72.631567 & 1.98 & 6.90 & 27.9 & 8.20 & 0.61 & positive \\
\hline 8 & 18.498250 & -72.632067 & 1.52 & 7.35 & 27.2 & 9.62 & 0.52 & positive \\
\hline 9 & 18.509617 & -72.630550 & 1.58 & 6.86 & 28.5 & 16.39 & 0.31 & positive \\
\hline 10 & 18.509267 & -72.630950 & 1.71 & 6.94 & 29.0 & 10.75 & 0.46 & positive \\
\hline 11 & 18.509967 & -72.632433 & $>1.74$ & & & dry well & & \\
\hline 12 & 18.506433 & -72.608383 & $>12.34$ & & & dry well & & \\
\hline 13 & 18.505867 & -72.608417 & $>12.50$ & & & dry well & & \\
\hline 14 & 18.512850 & -72.623067 & 4.57 & 7.06 & 28.2 & 13.16 & 0.38 & positive \\
\hline 15 & 18.512683 & -72.622917 & 5.49 & 7.08 & 28.2 & 16.39 & 0.31 & positive \\
\hline 16 & 18.512650 & -72.624967 & 3.51 & 7.52 & 27.6 & 11.11 & 0.44 & positive \\
\hline 17 & 18.513900 & -72.624933 & 3.69 & 7.23 & 27.9 & 15.63 & 0.32 & positive \\
\hline 18 & 18.514217 & -72.624183 & 3.60 & 7.05 & 28.4 & 14.29 & 0.35 & positive \\
\hline 19 & 18.514100 & -72.625183 & 3.44 & 7.24 & 28.5 & 15.15 & 0.33 & positive \\
\hline 20 & 18.514167 & -72.626000 & 2.96 & 7.33 & 28.4 & 16.13 & 0.31 & positive \\
\hline 21 & 18.509193 & -72.627085 & $>3.05$ & & & dry well & & \\
\hline 22 & 18.509433 & -72.627483 & $>3.81$ & & & dry well & & \\
\hline 23 & 18.513050 & -72.627167 & 2.80 & 7.06 & 28.8 & 12.66 & 0.40 & positive \\
\hline 24 & 18.513700 & -72.626567 & 2.80 & 7.13 & 28.3 & 14.93 & 0.33 & positive \\
\hline 25 & 18.513433 & -72.626633 & $>1.83$ & & & dry well & & \\
\hline 26 & 18.513683 & -72.626867 & 2.53 & 7.43 & 28.5 & 4.98 & 1.00 & positive \\
\hline 27 & 18.513767 & -72.626117 & 3.08 & 7.32 & 28.2 & 13.51 & 0.37 & positive \\
\hline 28 & 18.514050 & -72.626167 & 3.17 & 7.20 & 28.4 & 18.52 & 0.27 & positive \\
\hline 29 & 18.508133 & -72.626933 & $>3.96$ & & & dry well & & \\
\hline 30 & 18.508417 & -72.623700 & 5.27 & & water de & hed too hazard & to sample & \\
\hline 31 & 18.502250 & -72.624100 & 5.33 & 7.27 & 29.9 & 10.10 & 0.49 & positive \\
\hline 32 & 18.508900 & -72.633233 & 1.37 & 7.35 & 26.8 & 9.90 & 0.50 & positive \\
\hline 33 & 18.516283 & -72.643217 & artesian & 7.83 & 27.2 & 25.00 & 0.20 & negative \\
\hline 34 & 18.512917 & -72.633800 & 0.00 & 7.42 & 28.9 & 15.63 & 0.32 & positive \\
\hline 35 & 18.512850 & -72.633917 & 0.00 & 7.48 & 29.0 & 13.51 & 0.37 & positive \\
\hline 36 & 18.508400 & -72.632400 & 0.00 & 7.19 & 28.6 & 15.63 & 0.32 & positive \\
\hline 37 & 18.511867 & -72.637200 & artesian & 7.51 & 28.1 & 17.54 & 0.28 & negative \\
\hline 38 & 18.509917 & -72.632750 & 1.49 & 7.29 & 28.2 & 11.63 & 0.43 & positive \\
\hline 39 & 18.510328 & -72.633809 & 2.04 & 7.24 & 28.5 & 11.49 & 0.43 & positive \\
\hline 40 & 18.513700 & -72.637150 & 0.70 & 7.59 & 28.1 & 9.17 & 0.55 & positive \\
\hline 41 & 18.513783 & -72.637150 & 0.40 & \multicolumn{5}{|c|}{ well full of trash; not sampled } \\
\hline 42 & 18.510117 & -72.632600 & artesian & 7.57 & 28.6 & 21.28 & 0.24 & negative \\
\hline 43 & 18.502017 & -72.614100 & 11.84 & 7.45 & 28.5 & 8.40 & 0.60 & positive \\
\hline 44 & 18.511069 & -72.632731 & artesian & 7.52 & 27.4 & 23.26 & 0.21 & negative \\
\hline 45 & 18.511069 & -72.632731 & artesian & 7.52 & 27.4 & 23.26 & 0.21 & negative \\
\hline
\end{tabular}




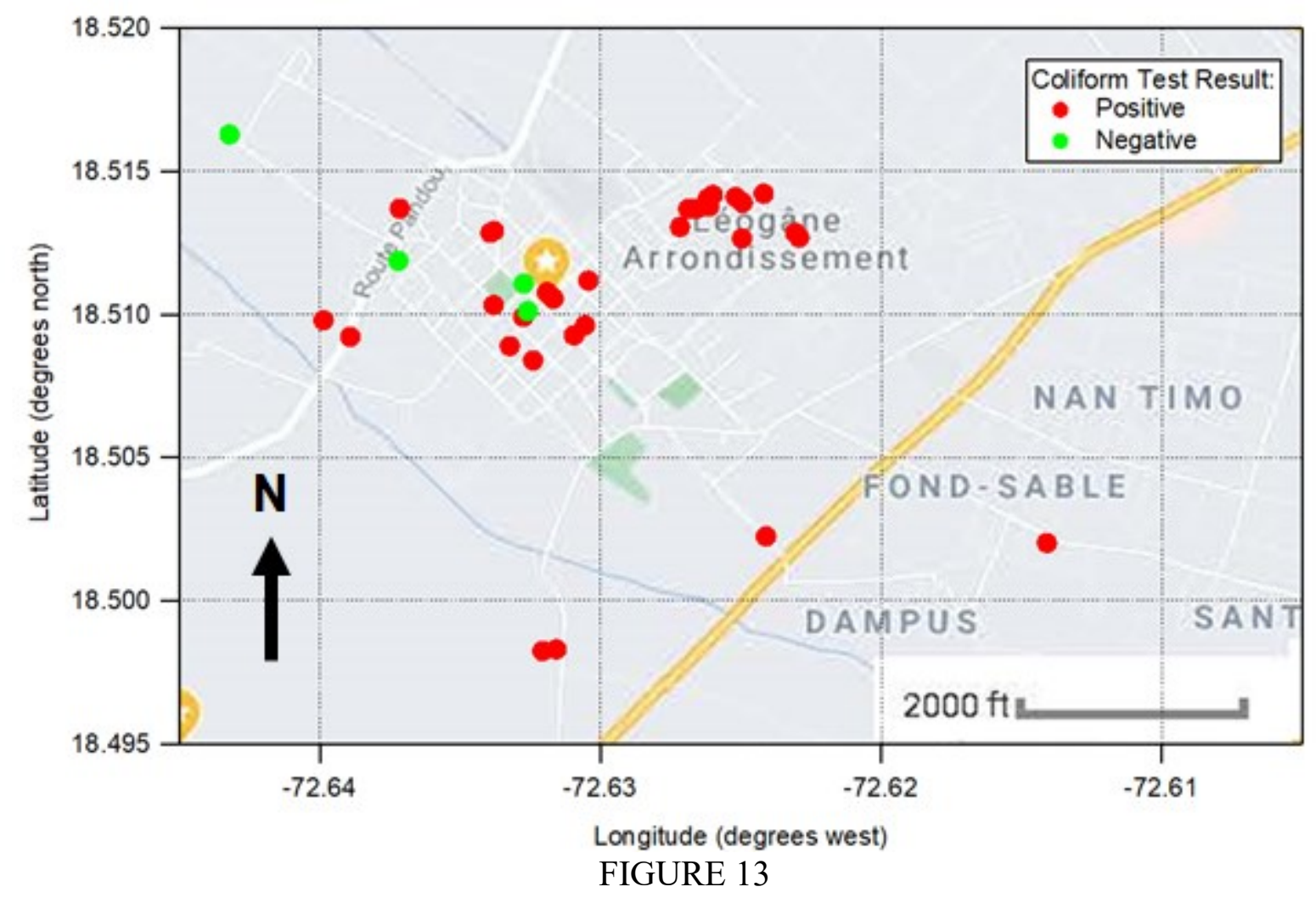

MAP SHOWING LOCATION OF COLIFORM TESTING OF GROUNDWATER; POSITIVE TESTS OCCURRED IN THE SHALLOW AQUIFER AND NEGATIVE TESTS OCCURRED IN THE DEEPER ARTESIAN AQUIFER.

A total of 14 DC resistivity soundings were acquired as summarized in Table 2. Weather conditions were dry and sunny during the testing period, so near-surface effects from standing water and a saturated ground surface were considered to be minimal. The apparent resistivity curves derived from field testing were inverted using the Interpex IX1D software to develop soundings of true resistivity versus depth. Typical apparent resistivity profiles and inverted true resistivity soundings are shown in Figs. 14 and 15, respectively. Drops in electrical resistivity were interpreted as the depth to the top of the water table, which are included in Table 2. 
International Journal for Service Learning in Engineering, Humanitarian Engineering and Social Entrepreneurship Vol. 16, No. 1, pp. 1-19, Spring 2021

ISSN 1555-9033

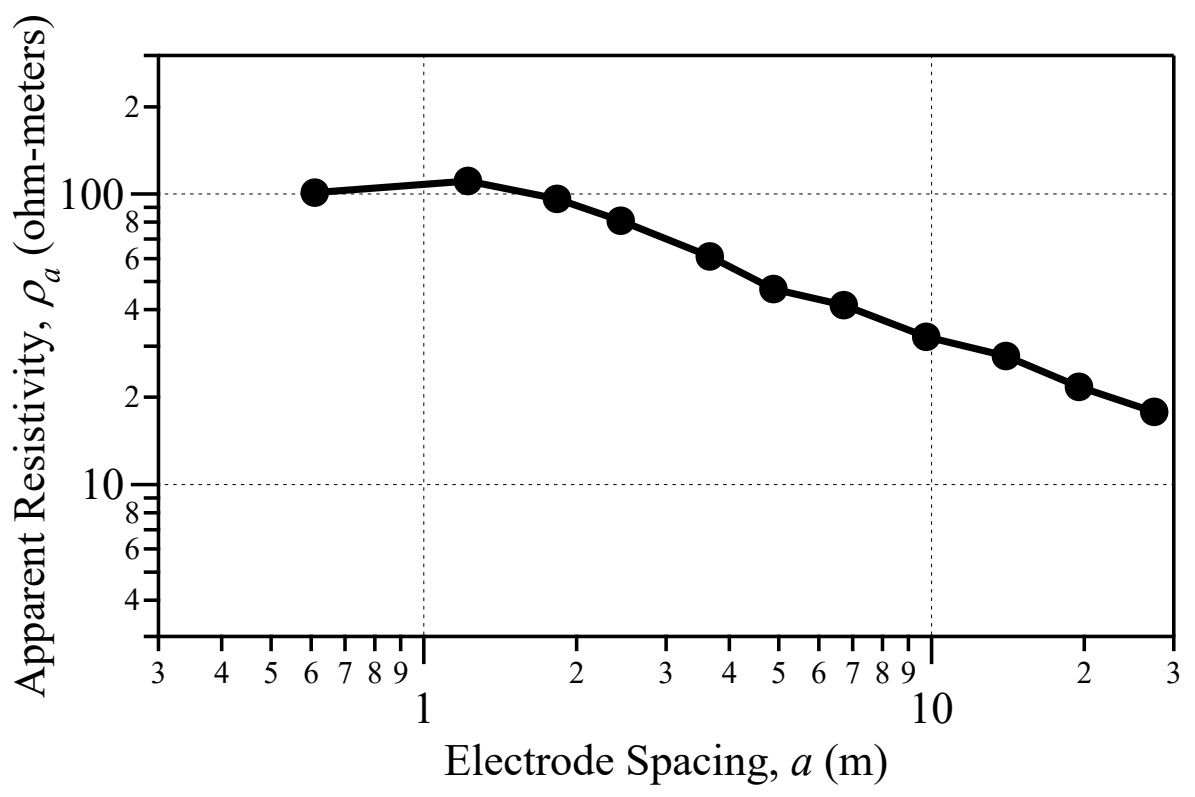

FIGURE 14

TYPICAL APPARENT RESISTIVITY CURVE DERIVED FROM FIELD TESTING AT THE LOCATION SHOWN IN FIG. 12 (SOUNDING “e”).

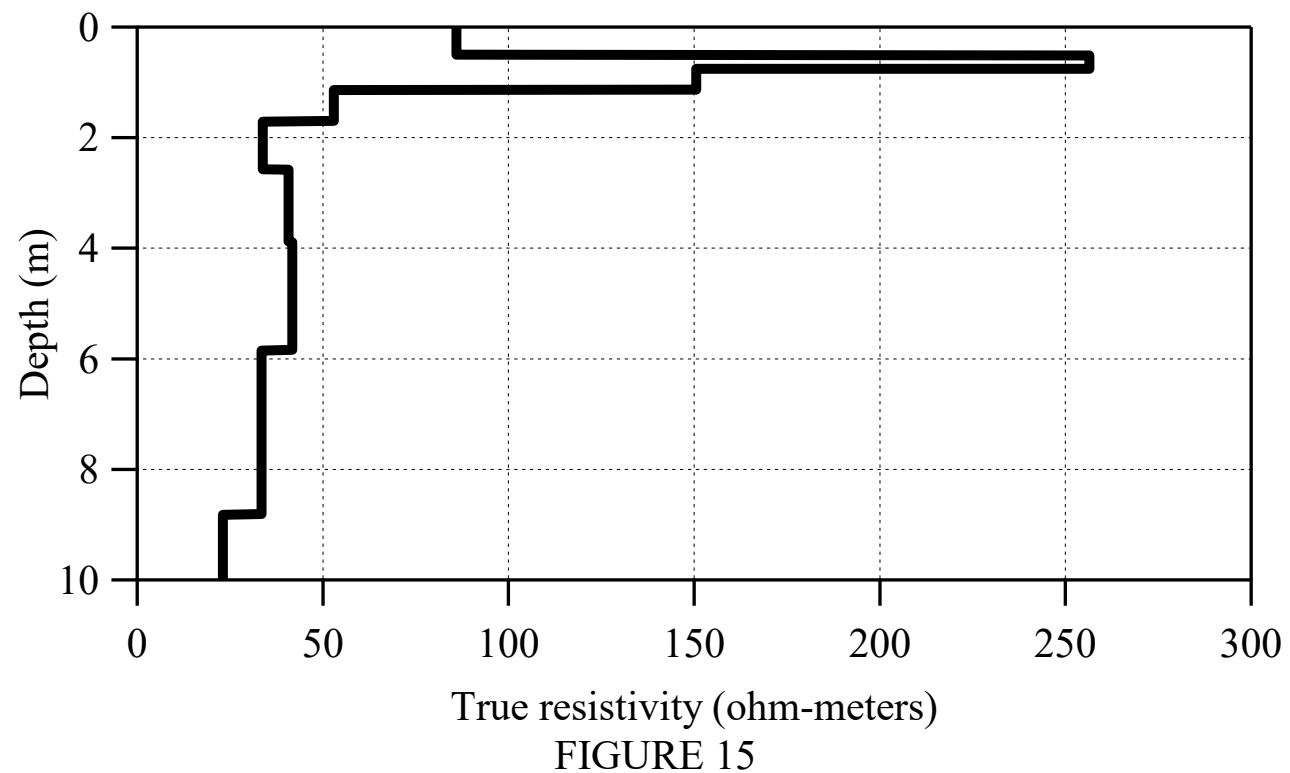

TYPICAL INVERTED TRUE RESISTIVITY SOUNDING DERIVED FROM INVERSION OF THE APPARENT RESISTIVITY CURVE SHOWN IN FIG. 14 (SOUNDING “e”). THE WATER TABLE DEPTH IS ESTIMATED TO BE APPROXIMATELY 1.1 M.

The average resistivity of the saturated soil was calculated for each geophysical sounding (Table 3). Soil resistivity was also estimated based on a relationship presented in literature by other researchers ${ }^{9,10}$. Soil resistivity, $\rho_{o}$, can be expressed as a function of the resistivity of the water in the pore spaces, $\rho_{w}$, as: 
$\frac{1}{\rho_{o}}=a\left(\frac{1}{\rho_{w}}\right) \theta^{2}+b\left(\frac{1}{\rho_{w}}\right) \theta+\frac{1}{\rho_{s}}$

where

$a=$ regression coefficient (recommended value $=1.3$ );

$b=$ regression coefficient (recommended value $=-0.1$ );

$\theta=$ volumetric water content (recommended value $=0.4$ ); and

$\rho_{s}=$ resistivity of soil solids (recommended value $=41.67 \mathrm{ohm}-\mathrm{m}$ ).

Resistivities are expressed in units of ohm-m in Eqn. 2 and recommended values for $a, b, \theta$ and $\rho_{s}$ are taken from the referenced literature.

TABLE 2

DATA OBTAINED FROM ELECRICAL DC RESISTIVITY TESTING IN LEOGANE.

\begin{tabular}{cccc}
\hline Sounding & Latitude $($ deg. N) & Longitude $($ deg. W) & Estimated Water Depth $(\mathrm{m})$ \\
\hline a & 18.507750 & -72.637350 & 0.5 \\
b & 18.510483 & -72.640083 & 0.5 \\
c & 18.505117 & -72.608517 & 12.5 \\
d & 18.516200 & -72.626583 & 3.9 \\
e & 18.510833 & -72.633733 & 1.1 \\
f & 18.509200 & -72.627083 & 3.5 \\
g & 18.507733 & -72.627267 & 3.5 \\
h & 18.515717 & -72.630183 & 2.0 \\
i & 18.508400 & -72.623833 & 5.1 \\
j & 18.501983 & -72.624433 & 4.0 \\
k & 18.514667 & -72.639450 & 0.5 \\
l & 18.511750 & -72.637417 & 0.5 \\
m & 18.518367 & -72.634300 & 0.5 \\
n & 18.513700 & -72.622683 & 4.5 \\
\hline
\end{tabular}

The calculated estimates for $\rho_{o}$ are included in Table 3 for comparison with the values derived from the geophysical testing. Soil resistivity can easily vary by orders of magnitude depending on factors such as soil mineralogy and soil density, so the differences reported in Table 3 are relatively minor. The differences in Table 3 demonstrate that the values for $\rho_{o}$ derived from geophysical testing are reasonable and consistent with the values of $\rho_{w}$ of the water samples recovered from nearby wells.

The measured depth to the water table from the wells and the interpreted depth to the water table from the resistivity soundings were combined to create a map illustrating the depth to the water table for the entire city of Leogane (Fig. 16). Most of the wells in Leogane were shallow hand-dug wells with a relatively shallow depth to the water table similar to the well shown in Fig. 3. All of these wells tested positive for coliforms, which is attributed to the practice of placing latrines in close proximity to the wells. Residents typically boil this water before consuming it, although some claim to consume it as is on a regular basis with no negative health effects.

When the map depicting the depth to the water table (Fig. 16) is compared to a map of the new pavement system (Fig. 1), there is no apparent correlation between the presence of the new pavement system and the depth to the water table. Combining the shallow aquifer map with the 
observations of the deeper artesian aquifer, a generalized cross-section showing the two aquifers underlying Leogane was generated that shows the presence of two distinct aquifers (Fig. 17).

TABLE 3

COMPARISON BETWEEN SOIL RESISTIVITY VALUES DERIVED USING GEOPHYSICAL MEASUREMENTS AND WATER WELL MEASUREMENTS.

\begin{tabular}{|c|c|c|c|c|c|}
\hline \multicolumn{2}{|c|}{ Geophysical Measurements } & \multicolumn{3}{|c|}{ Water Well Measurements } & \multirow{2}{*}{$\begin{array}{c}\text { Difference between soil resistivity } \\
\text { based on inversion and } \\
\text { soil resistivity based on Eqn. } 2 \\
(\%)\end{array}$} \\
\hline Sounding & $\begin{array}{c}\text { Soil resistivity } \\
\text { based on inversion, } \\
\rho_{o}(\mathrm{Ohm}-\mathrm{m})\end{array}$ & $\begin{array}{l}\text { Nearest } \\
\text { well with } \\
\text { water }\end{array}$ & $\begin{array}{c}\text { Water } \\
\text { resistivity, } \\
\rho_{w}(\text { Ohm-m })\end{array}$ & $\begin{array}{c}\text { Soil resistivity } \\
\text { based on Eqn. } 2 \text {, } \\
\rho_{o}(\mathrm{Ohm}-\mathrm{m})\end{array}$ & \\
\hline $\mathrm{a}$ & 13.7 & 5 & 8.2 & 22.5 & 64.1 \\
\hline $\mathrm{b}$ & 17.5 & 4 & 6.0 & 19.1 & 9.4 \\
\hline $\mathrm{c}$ & 64.9 & 43 & 8.4 & 22.7 & -65.0 \\
\hline $\mathrm{d}$ & 20.0 & 20 & 16.1 & 29.1 & 45.3 \\
\hline $\mathrm{e}$ & 34.2 & 39 & 11.5 & 25.9 & -24.3 \\
\hline $\mathrm{f}$ & 30.8 & 9 & 16.4 & 29.2 & -5.2 \\
\hline $\mathrm{g}$ & 30.8 & 9 & 16.4 & 29.2 & -5.2 \\
\hline $\mathrm{h}$ & 17.6 & 35 & 13.5 & 27.4 & 55.9 \\
\hline $\mathrm{i}$ & 31.9 & 31 & 10.1 & 24.6 & -22.9 \\
\hline $\mathrm{j}$ & 71.6 & 31 & 10.1 & 24.6 & -65.6 \\
\hline $\mathrm{k}$ & 21.6 & 40 & 9.2 & 23.6 & 9.4 \\
\hline 1 & 22.9 & 5 & 8.2 & 22.5 & -1.8 \\
\hline $\mathrm{m}$ & 28.9 & 40 & 9.2 & 23.6 & -18.2 \\
\hline \multirow[t]{2}{*}{$\mathrm{n}$} & 29.6 & 14 & 13.2 & 27.2 & -8.1 \\
\hline & & & & & Average $=-2.3 \%$ \\
\hline
\end{tabular}

\section{CONCLUSIONS}

Several important lessons were learned that will help direct future humanitarian efforts in Haiti and elsewhere, including:

- The project team could not conclude that there was a correlation between the new pavement system and the depth to the water table. Changes in the water table in Leogane are likely related to the earthquake itself and seasonal variations in precipitation patterns.

- There are two distinct water-bearing aquifers in Leogane, including a shallow aquifer and a deeper aquifer that produces artesian wells.

- The shallow aquifer in Leogane contains coliforms in virtually every well in Leogane due to the widespread use of latrines.

- The deeper artesian aquifer in Leogane is hydraulically isolated from the shallow aquifer and bears clean, coliform-free water.

- Any efforts to drill through the shallow contaminated aquifer into the deeper clean aquifer should proceed with caution to avoid cross-contamination and impacting the deeper aquifer.

- The methodology presented herein represents a relatively simple approach to mapping groundwater and assessing water quality that can be easily applied to other communities 
International Journal for Service Learning in Engineering, Humanitarian Engineering and Social Entrepreneurship Vol. 16, No. 1, pp. 1-19, Spring 2021

ISSN 1555-9033

in the developing world to guide their efforts to develop and manage groundwater resources.

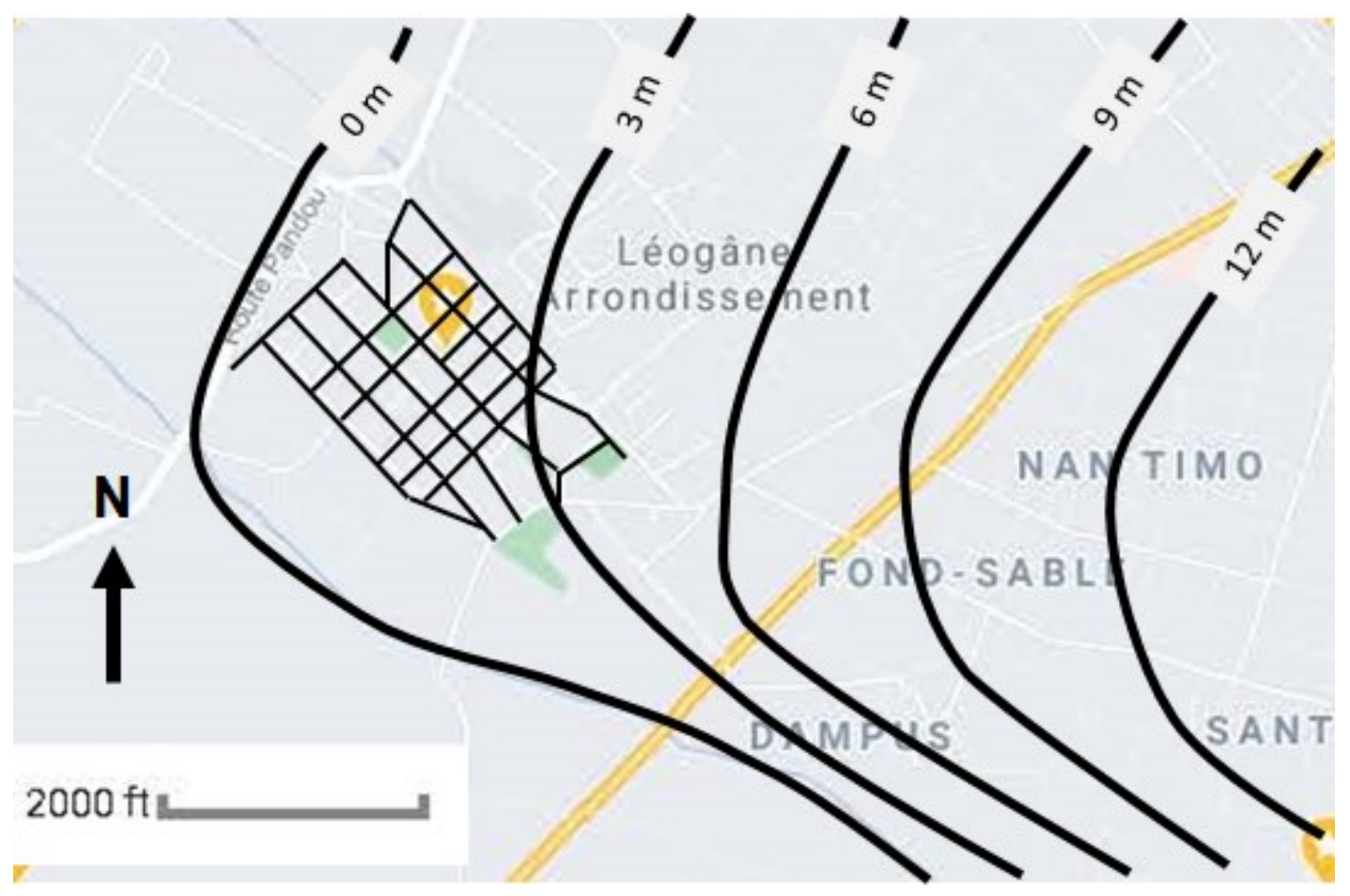

FIGURE 16

CONTOUR MAP SHOWING DEPTH TO SHALLOW UNCONFINED AQUIFER BASED ON RESULTS FROM WATER WELL SURVEYING AND DC RESISTIVITY SOUNDING.

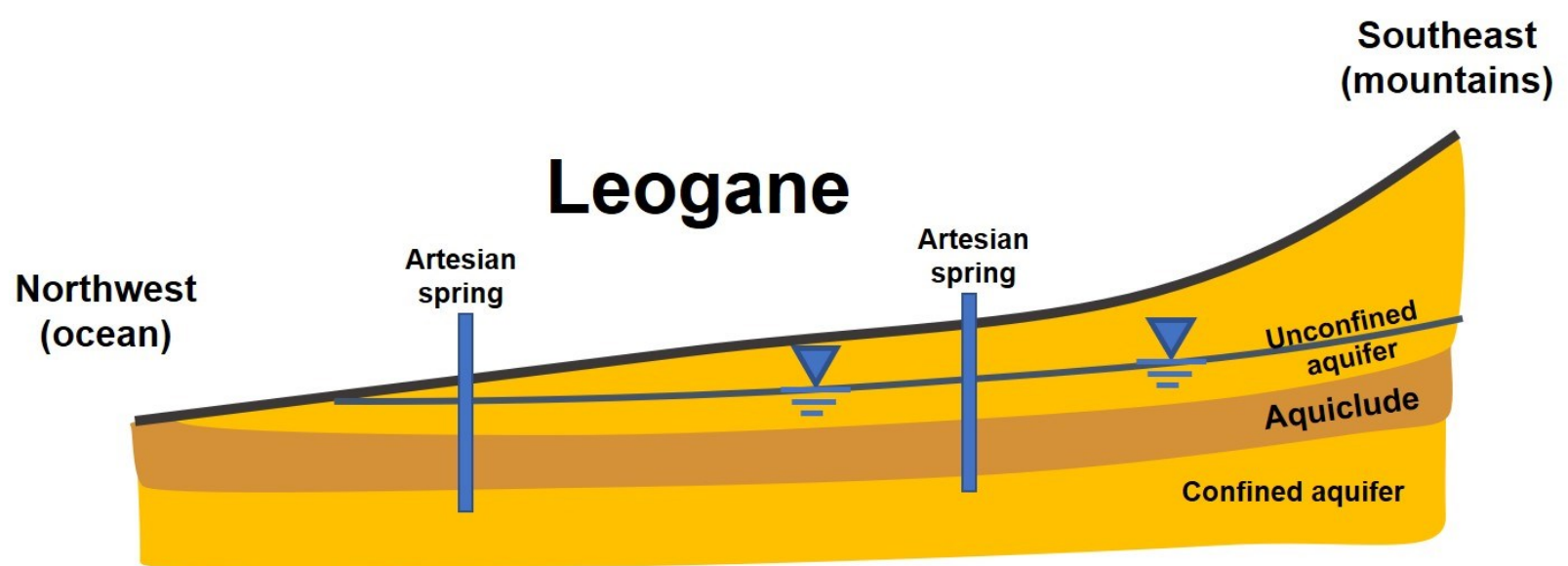

FIGURE 17

SCHEMATIC CROSS-SECTION OF LEOGANE SHOWING A SHALLOW UNCONFINED AQUIFER AND A DEEPER CONFINED AQUIFER ASSOCIATED WITH ARTESIAN WELLS. 
Herein, an approach was presented to apply the DC resistivity geophysical method to aid in groundwater mapping in a developing nation. This is an attractive method because of its simplicity, low cost and ease of use. Limitations to applying the method include the need to test along an unobstructed distance of around $100 \mathrm{~m}$ and the need to test on grass or soil rather than pavement, which can be difficult to find in a congested urban setting. These limitations may be overcome by applying an alternative geophysical method such as time-domain electromagnetics (TDEM) ${ }^{5}$. Equipment to perform TDEM testing is more expensive, but the method can be used to quantify variations in soil resistivity with depth without the need for long a straight distance or an unpaved surface, although data quality can be affected by background electromagnetic noise.

In general, the resistivity soundings generated using the DC resistivity method provided conclusive information to help map the water table. However, there were some instances where identification of a contrast in electrical resistivity indicative of the top of the water table was less conclusive. In these instances, it is likely that fine-grained soil above the water table was nearly saturated due to the surface tension of the ground water and capillary stresses between the soil particles. In areas where a geophysical method is needed to estimate the depth to the water table in fine-grained soils, it may be advantageous to use the refraction seismic geophysical method $^{5}$. Refraction seismic testing involves the propagation and measurement of seismic P-waves as they pass along soil and rock layer boundaries near the ground surface. Since P-waves travel at a different speed depending on whether they are propagating above or below the water table, they can be used to estimate the depth to the water table. The refraction seismic method is relatively equipment-intensive compared to the DC resistivity method used in Leogane and it also requires a long stretch of unobstructed ground, but it may be a valuable tool for groundwater mapping.

The results of this investigation were communicated to the community by Haiti Engineering, who assisted with the field logistics and data acquisition activities. The residents of the community were not surprised by the results from coliform testing of the well water but were reassured knowing that water from the deeper artesian wells in Leogane was found to be coliform-free. Having demonstrated that the drop in the water table was not caused by the new pavement, the residents concluded that the drop was caused by the earthquake ${ }^{11}$ and by seasonal variations in precipitation.

\section{ACKNOWLEDGMENTS}

The authors would like to thank the Society of Exploration Geophysicists Geoscientists Foundation and Geoscientists Without Borders for their generous funding of this project, along with the people of Leogane, Haiti for their kindness and hospitality.

\section{REFERENCES}

\footnotetext{
${ }^{1}$ World Bank, 2019, "Economic Information on Haiti," http://www.worldbank.org/en/country/haiti, World Bank (accessed April 5, 2021).

${ }^{2}$ Cavallo, E. A., Powell, A. and Becerra, O., 2010, "Estimating the Direct Economic Damage of the Earthquake of Haiti," IDB Working Paper Series No. IDB-WP-163, Inter-American Development Bank, Department of Research and Chief Economist, February 2010.
} 
International Journal for Service Learning in Engineering, Humanitarian Engineering and Social Entrepreneurship Vol. 16, No. 1, pp. 1-19, Spring 2021

ISSN 1555-9033

3 JICA, 2010, "Urban Road Improvement Plan for Rehabilitation of Leogane City," https://translate.google.com/translate?hl=en\&sl=ja\&u=https:/www.jica.go.jp/oda/project/1060690/\&prev=search, Japan International Cooperation Agency (accessed April 5, 2021).

4 World Weather Online, 2021, "Leogane Monthly Climate Averages," https://www.worldweatheronline.com/leogane-weather-averages/ouest/ht.aspx (accessed April 5, 2021).

${ }^{5}$ Reynolds, J. M., 2011, An Introduction to Applied and Environmental Geophysics, Second Edition, WileyBlackwell, ISBN 978-0-471-48536-0.

${ }^{6}$ Dahlin, T., 1996, "2D Resistivity Surveying for Environmental and Engineering Applications," First Break, Vol. 14, pp. 275-284.

${ }^{7}$ Manja, K. S., Maurya, M. S. and Rao, K. M., 1982, "A Simple Field Test for the Detection of Faecal Pollution in Drinking Water," Bulletin of the World Health Organization, Vol. 60, No. 5, pp. 797-201.

${ }^{8}$ USEPA, 2019, "Drinking Water Regulations and Contaminants," https://www.epa.gov/dwregdev/drinking-waterregulations-and-contaminants, United States Environmental Protection Agency (accessed April 5, 2021).

${ }^{9}$ Kalinski, R. J. and Kelly, W. E., 1993, "Estimating Water Content of Soils from Electrical Resistivity," Geotechnical Testing Journal, Vol. 16, No. 3, pp. 323-329.

${ }^{10}$ Rhoades, J. D., Raats, P. A. C. and Prather, R., J., 1976, "Effects of Liquid-phase Electrical Conductivity, Water Content and Surface Conductivity on Bulk Soil Electrical Conductivity," Journal of the Soil Science Society of America, Vol., 40, p. 651-655.

${ }^{11}$ USGS, 2021, "Groundwater-Level Response to Earthquakes," https://water.usgs.gov/ogw/bgas/eq-gw/\#1, United States Geological Survey (accessed April 1, 2021). 